\title{
Structural Characteristics of Natural Limestone Forests in Cat Ba Biosphere Reserves, Vietnam
}

\author{
Tran Hai Long ${ }^{1,2^{*}}$, I. M. Sangjun ${ }^{2}$, Trieu Thai Hung ${ }^{1}$, Qiwen Li $^{2}$, \\ Ninh Viet Khuong ${ }^{1}$, Nguyen Van Tuan ${ }^{1}$, Tran Hoang Quy ${ }^{1}$, Trinh Ngoc Bon ${ }^{1}$, \\ Tran Cao Nguyen ${ }^{1}$, Le Thi Thu Hang ${ }^{3}$ and Tran Van Do ${ }^{1}$
}

${ }^{1}$ Silviculture Research Institute, Vietnamese Academy of Forest Sciences, 46 Duc Thang, Bac Tu Liem, Hanoi, Vietnam.

${ }^{2}$ Department of Agriculture, Forestry, and Bioresources, Seoul National University, 1 Gwanak-ro, Gwanak-gu, Seoul 08826, Republic of Korea. ${ }^{3}$ Research Institute for Forest Ecology and Environment, Vietnamese Academy of Forest Sciences, 46 Duc Thang, Bac Tu Liem, Hanoi, Vietnam.

Authors' contributions

This work was carried out in collaboration among all authors. Authors THL, IMS and TTH designed the study. Authors THL, LTTH and QL performed the statistical analysis. Authors NVK, NVT, THQ,

TNB and TCN conducted fieldwork. Authors THL and TVD wrote the first draft. Authors IMS and TTH managed the analyses of the study. All authors read and approved the final manuscript.

\section{Article Information}

DOI: $10.9734 / A R R B / 2020 / v 35 i 1230321$ Editor(s):

(1) Paola Angelini, University of Perugia, Italy.

Reviewers:

(1) Prosanta Hazarika, Rain Forest Research Institute, Jorhat, India.

(2) Jalajakshi S., Vijaya College, India Complete Peer review History: http://www.sdiarticle4.com/review-history/64612

Original Research Article

Received 25 October 2020

Accepted 29 December 2020

Published 31 December 2020

\section{ABSTRACT}

An ecological understanding of natural forests after anthropogenic intervention is important for sustainable forest management. This study analyzed the overstory characteristics (species composition, growth, and diameter distribution) and regeneration (species richness, density, and height distribution) in natural limestone forests in Cat Ba Biosphere Reserve, Vietnam. Data were collected in nine study plots established in selective-logged (SLF), clear-cut (CCF), and unlogged (UF) forests. Results indicated that the overstory characteristics of SLF and CCF were lower than that of UF (species richness was 33 in UF, 20 in SLF, and 16 in CCF; DBH was $20.6 \pm 13.7 \mathrm{~cm}$ in 
UF, $16.9 \pm 9.7 \mathrm{~cm}$ in SLF, and $10.5 \pm 3.8 \mathrm{~cm}$ in CCF; Basal area was $38.2 \mathrm{~m}^{2} \mathrm{ha}^{-1}$ in UF, $24.0 \mathrm{~m}^{2} \mathrm{ha}^{-1}$ in SLF, and $11.4 \mathrm{~m}^{2} \mathrm{ha}^{-1}$ in CCF). For regeneration, species richness also varied from UF (25) to SLF (13) and CCF (5), while seedling density reversely increased. We concluded that a 20-year restoration was insufficient for artificially disturbed forests to recover their ecological functions, regardless of logging intensities and techniques applied.

Keywords: Natural limestone forest; forest harvesting, overstory; regeneration; forest restoration.

\section{INTRODUCTION}

Forests on limestone are widely distributed in the tropics, especially in Southeast Asia, northern Central America, Brazil, and the Greater Antilles. Tropical limestone forests occupy around $40 \%$ of the total tropical Asian landscape area [1]. Tropical forests on limestone are known as significant high biodiversity communities with many endemic species [2-5]. They form a particularly abundant endemic flora and have high environmental heterogeneity due to largescale changes in substrate solubility [6]. However, vegetation over limestone, or more particularly limestone forest is highly susceptible to environmental disturbance, while strong artificial perturbation can reverse their succession process, and restoration is difficult [7]. Moreover, limestone forest is more vulnerable to damages because of its typical shallow and patchy soil horizon, extremely slow soil formation with highly porous from the underlying limestone, characterizing with low water-retention capacity $[8,9]$. It is even considered as one of the most threatened and fragile vegetation types on the earth $[10,11]$.

Human intervention, especially logging, has long been considered to be one of the main causes of tropical forest deforestation and forest degradation despite increasing protection and conservation efforts $[12,13]$. In 2005, more than $21 \%$ of the humid tropical forests were selectively logged, becoming the most widespread method of logging in the tropics and larger than clear-cut related methods previously applied [12]. This rise of logged forests makes the restoration and conservation of the tropical forest structure and biodiversity heavily dependent on the sustainability of logging methods [14].

Few studies have intensively investigated tropical limestone forests overall and those that had previously been affected by anthropogenic stresses in particular. However, the existing researches on the structure of this type of forest has contributed to raising the understanding on one of previously poorly studied subjects in forest ecology $[15,16]$. On the other hand, forest management and silvicultural practices require not only information on tree species composition and forest structure, but also the plant diversity [17,18]. Previous studies have also emphasized the importance of field surveys to improve our understanding of tree diversity in tropical limestone forests, especially in Central and South America $[6,15,19]$.

The objective of the present study was to compare the differences in overstory characteristics and regeneration among selective-logged (SLF), clear-cut (CCF), and unlogged (UF) forests after 20-year protection in Cat Ba Biosphere Reserve, Vietnam.

\section{MATERIALS AND METHODS}

\subsection{Study Area}

This study was conducted in the Cat $\mathrm{Ba}$ Biosphere Reserves (2044'50"-20 $55^{\prime} 29^{\prime \prime} \mathrm{N}$, $\left.106^{\circ} 54^{\prime} 20^{\prime \prime}-107^{\circ} 10^{\prime} 05^{\prime \prime} \mathrm{E}\right)$ in Northeastern, Vietnam (Fig. 1). The Cat $\mathrm{Ba}$ Biosphere Reserves has a total area of 26,241 ha with 17,040 ha of landmass and 9,201 ha of the marine environment. It is located in the tropical monsoon climate with an average annual rainfall of $1,700-1,800 \mathrm{~mm}$. The average temperature is $25-28^{\circ} \mathrm{C}$ (max. $36^{\circ} \mathrm{C}$ and $\min .10^{\circ} \mathrm{C}$ ) and average humidity is $85 \%$ [20].

The Cat Ba Biosphere Reserves is characterized by a unique variety of landscapes and ecosystems, including limestone karsts, tropical limestone forests, coral reefs, mangroves, seagrass beds, lagoons, beaches, caves, and willow swamp forests [21]. It has a significant biodiversity value as it is home to a number of rare and endangered species of plants and animals with the world's rarest primates - the Golden-headed Langur. It is identified as one of the highest biodiversity areas in Vietnam and is 
recognized as a high priority for global conservation $[22,23]$.

The original vegetation in Cat $\mathrm{Ba}$ Biosphere Reserves was characterized by tropical evergreen broad-leaved forest developed on limestone bedrock before degradation in the 1970s [24]. The forests were subjected to overlogging by the legal and illegal, land-use shift to agriculture or annual crops and have been partly in the regeneration process at different stages since the 1990s [25]. Locations for setting up of sample plots were selected basing on their representativeness for each type of human impact (Table 1).

\subsection{Data Collection}

Nine sample plots of $400 \mathrm{~m}^{2}(20 \times 20 \mathrm{~m})$ were established, including 3 plots in UF, 3 plots in SLF, and 3 plots in CCF (Fig. 2). In each sample plot, all stems with a diameter at breast height $(\mathrm{DBH})$ ? 5 were identified to species and measured for $\mathrm{DBH}(\mathrm{cm})$. The canopy cover was measured by the ground-based method using a sighting tube in forest vegetation with a random sampling design. Four $5 \times 5 \mathrm{~m}\left(25 \mathrm{~m}^{2}\right)$ plots within each of the $400 \mathrm{~m}^{2}$ sample plots were set up to identify the species and survey the number of species and height of regenerated trees with $\mathrm{DBH}<5 \mathrm{~cm}$.

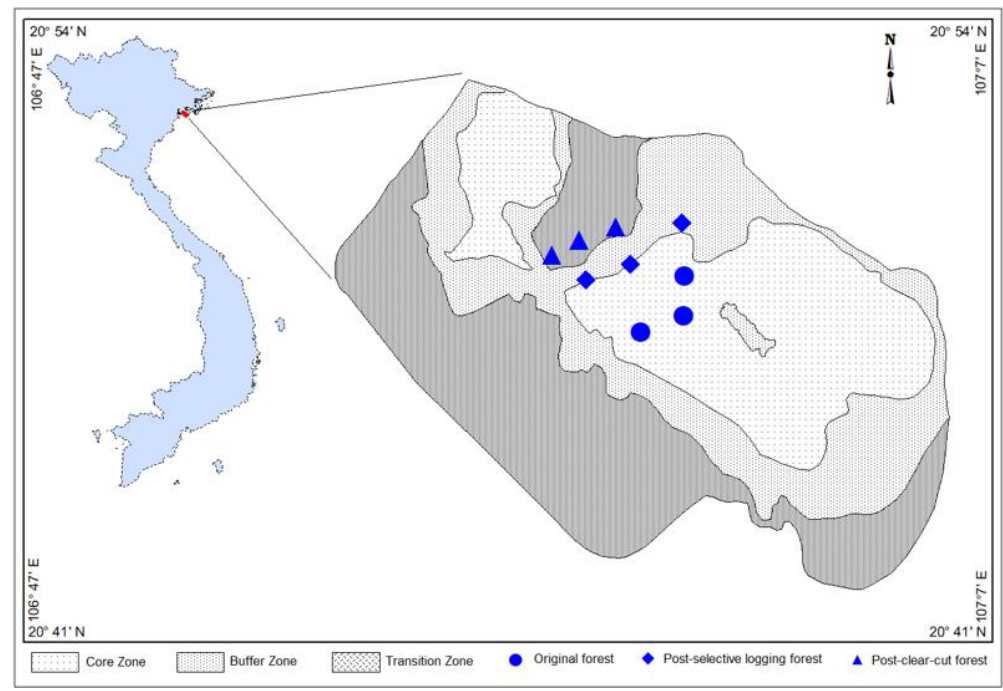

Fig. 1. Map of the study site with plot locations in the Cat Ba biosphere reserves

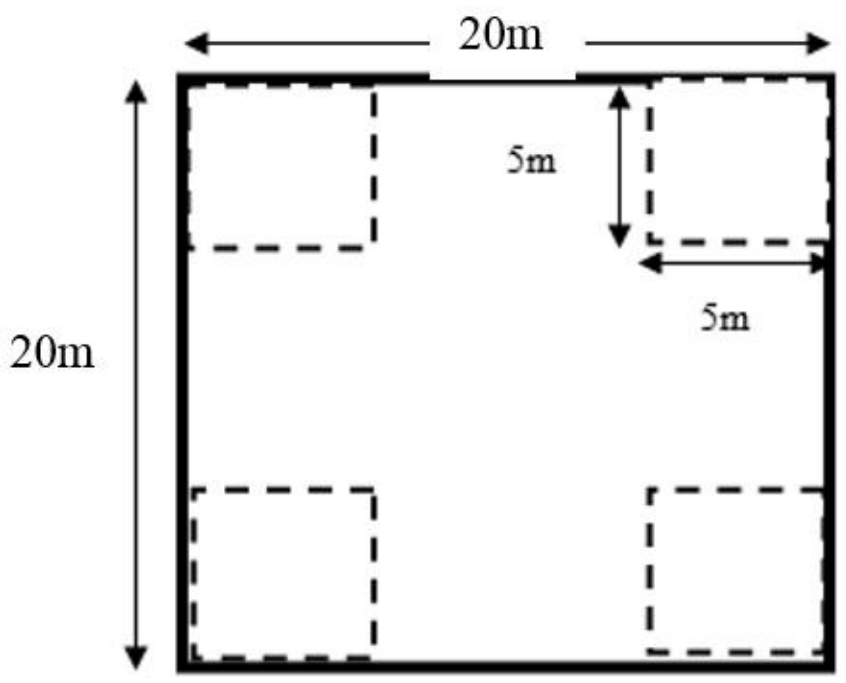

Fig. 2. Sample plot layout in the study site 
Long et al.; ARRB, 35(12): 161-172, 2020; Article no.ARRB.64612

Table 1. General characteristics of sample plots in the study area

\begin{tabular}{|c|c|c|c|c|c|c|}
\hline Plot & X coordinate & Y coordinate & $\begin{array}{l}\text { Sloping } \\
\text { (degree) }\end{array}$ & Altitude (m) & Forest type & Historical human impact \\
\hline UF1 & 629743 & 2301148 & 5 & 108 & Natural limestone forest & None \\
\hline UF2 & 631812 & 2300637 & 25 & 96 & Natural limestone forest & None \\
\hline UF3 & 631100 & 2300763 & 10 & 43 & Natural limestone forest & None \\
\hline SLF1 & 632171 & 2303182 & 20 & 122 & Natural limestone forest & $\begin{array}{l}\text { Selective logging completed - } \\
\text { Natural regeneration }\end{array}$ \\
\hline SLF2 & 629366 & 2305496 & 25 & 92 & Natural limestone forest & $\begin{array}{l}\text { Selective logging completed - } \\
\text { Natural regeneration }\end{array}$ \\
\hline SLF3 & 629311 & 2302878 & 7 & 61 & Natural limestone forest & $\begin{array}{l}\text { Selective logging completed - } \\
\text { Natural regeneration }\end{array}$ \\
\hline CCF1 & 627872 & 2297025 & 20 & 114 & Natural limestone forest & $\begin{array}{l}\text { Clear-cut completed - Natural } \\
\text { regeneration }\end{array}$ \\
\hline CCF2 & 625409 & 2304823 & 38 & 81 & Natural limestone forest & $\begin{array}{l}\text { Clear-cut completed - Natural } \\
\text { regeneration }\end{array}$ \\
\hline CCF3 & 625644 & 2305091 & 15 & 61 & Natural limestone forest & $\begin{array}{l}\text { Clear-cut completed - Natural } \\
\text { regeneration }\end{array}$ \\
\hline
\end{tabular}




\subsection{Data Analysis}

\subsubsection{Overstory}

Species composition was identified by using the Importance Value Index (IVI), calculated by Eq. 1 [26].

$$
I V I_{i}=\frac{N_{i}+G_{i}}{2}
$$

where $\quad \mathrm{IVI}_{\mathrm{i}}(\%)$ is the importance value of species $i^{\text {th }}, N_{i}$ is the stem ratio of species $i^{\text {th }}, G_{i}$ is the stem basal area of species $i^{\text {th }}$.

The total basal area for each plot was calculated by Eq. 2.

$$
G=3.1416 \times \frac{\left(\frac{D}{400}\right)^{2}}{400}
$$

where $G$ is the sum of the basal area of tree $\left(\mathrm{m}^{2}\right), \mathrm{D}$ is $\mathrm{DBH}(\mathrm{cm})$.

Canopy cover was identified as the percent forest area occupied by the vertical projection of tree crowns and calculated by Eq. 3 .

$$
C=\frac{N_{C}}{N_{t}}
$$

where $\mathrm{Nc}$ is the number of sample points covered by the canopy and $\mathrm{Nt}$ is the total number of points sampled.

\subsubsection{Species diversity}

Species diversity was estimated by Gini-Simpson index [27], Shannon - Weiner index (H') [28], and evenness index (J') [29]. These index were calculated from Eq. (4) (6) as follow.

$$
\begin{aligned}
& 1-\lambda=1-\sum_{i=1}^{S} p_{i}^{2} \\
& H^{\prime}=-\sum_{i=1}^{S} p_{i} \ln p_{i} \\
& J=\frac{H^{\prime}}{\ln (S)}
\end{aligned}
$$

where: $s$ is the number of species in the plot and $p_{i}$ is the proportion of individuals belonging to the $i^{\text {th }}$ species in the dataset.

\subsubsection{Statistical analysis}

Stand parameters including species diversity, $\mathrm{DBH}$, basal area, density, and canopy cover were calculated for each survey plot among three forest types separately.

The assumption of ANOVA (single factor) such as homogeneity of variance was checked for all variables. Tukey's protected least significant difference (LSD at $P=.05$ ) post hoc test was used to determine the differences of means of all measured parameters among three forest types. All analyses were performed using IBM SPSS Version 22.0 software package (IBM, Armonk, NY, USA).

\section{RESULTS AND DISCUSSION}

\subsection{Results}

\subsubsection{Overstory diversity and composition}

There was a significant difference in the number of species and families as well as biodiversity among UF, SLF, and CCF (Table 2). The UF had the highest number of species, families, and biodiversity values. These indices steadily decreased to the SLF and CCF forests.

In the UF (Table 3), the most dominant species were Engelhartia roxburghiana (IVI=11.3) and Dracontomelum duperreanum (9.6), which were slow-growing, high-value endemic species of Vietnam. In the SLF, Streblus macrophyllus (18.2) and Sacara dives (13.4) were the most dominant species, both are the pioneer and light-tolerant species. In the CCF, Ficus auriculata (25.0) and Streblus ilicifolius (17.1) dominated the forest, both were pioneers with low value and median growth. Furthermore, none of the species found in UF occurred in the other two forest types, while only two species (Streblus macrophyllus and Streblus ilicifolius) in SLF were also found in CCF. None of the species with IVI > 5 in UF belonged to the same family, while in SLF this figure was two, and for CCF it was three.

\subsubsection{Overstory growth characteristics}

Stem density increased from UF (800 stems ha ${ }^{-1}$ ) to SLF (817 stems ha $\left.^{-1}\right)$ and CCF $\left(1,117\right.$ stems ha $^{-}$ $\left.{ }^{1}\right)$. However, the average density between UF and SLF was not statistically different (Table 4). DBH decreased sharply from UF to SLF and CCF (Table 4). Basal area was significantly higher in UF $\left(38.2 \mathrm{~m}^{2} \mathrm{ha}^{-1}\right)$ than in SLF $\left(24 \mathrm{~m}^{2} \mathrm{ha}^{-1}\right)$ and CCF $\left(11.4 \mathrm{~m}^{2} \mathrm{ha}^{-1}\right)$. Canopy cover likewise was significantly higher in UF $(79.3 \%)$ than SLF $(62.4 \%)$ and CCF (52.7\%).

The diameter distribution (N/D) was varied among three forest types (Fig. 3). The UF had N/D by the Meyer and Distance functions. The SLF did not follow any distribution function. While N/D of the CCF followed the Distance function.

\subsubsection{Regeneration characteristics}

There was a significant difference in regenerated species richness between UF (35 species) and 
the other two forest types (13 species in SLF and 5 species in CCF) (Table 5).

The number of regenerated species in UF was significantly higher than that in the overstory layer (35-33 species, a $5.7 \%$ increase from the overstory). While SLF and CCF had a lower number of regenerated species than overstory species (12-20 species, a 37\% reduction in SLF; $6-16$ species, a $43.1 \%$ reduction in CCF) (Table 2).

The density of regenerated species decreased from CCF $\left(43,573\right.$ seedlings ha $\left.^{-1}\right)$ to SLF $(21,733$ seedlings $\left.\mathrm{ha}^{-1}\right)$ and UF (8,373 seedlings $\left.\mathrm{ha}^{-1}\right)$. Most seedlings are in a height class of $<0.5 \mathrm{~m}$, the seedling number decreased in higher height classes (Fig. 4). The density of regenerated species in CCF decreased rapidly from 31,120 seedlings ha ${ }^{-1}$ at $<0.5 \mathrm{~m}$ to 2,293 seedlings $\mathrm{ha}^{-1}$ at $>1 \mathrm{~m}$. Meanwhile, in the SLF 10,960 seedlings $\mathrm{ha}^{-1}$ at $<0.5 \mathrm{~m}$ decreased to 3,797 seedlings $\mathrm{ha}^{-1}$ at $>1 \mathrm{~m}$, and in UF 5,147 seedlings ha- ${ }^{-1}$ at $<0.5 \mathrm{~m}$ decreased to only 880 seedlings ha ${ }^{-1}$ at $>1 \mathrm{~m}$.

\subsection{Discussion}

\subsubsection{Overstory diversity and composition}

Biodiversity in the studied forests appeared to be highly affected by exploitation intensities, showing the UF had much higher diversity indices than the two logged forest types. This might be explained by the fact that under natural or unaffected conditions, the diversity of limestone forest would be high $[18,30]$. For SLF and $\mathrm{CCF}$, the lower values of biodiversity were due to the shortage of seedlings and the previous human activities [17,18,31]. However, this finding was in contrast with other studies where they indicated that the formation of gaps in the unstable forest canopy created by logging activity is a favorable condition for the growth of many tree species, thus allowing the appearance of new species, especially light-demanding pioneers previously unable to grow under oldgrowth forest canopy $[32,33]$.

On the other hand, the biodiversity of natural limestone forests in the study area was much lower than that of other evergreen forests in Vietnam and neighboring countries with similar ecological characteristics. The $\mathrm{H}^{\prime}$ index in Xishuangbanna-China was $3.02-3.89$, while in Ba Be National Park - Vietnam varied from 1.9 to $3.61[34,35]$. It was also lower than the limestone forest in Sarawak - Malaysia where H' was 3.0 -
3.7 [36]. The D' index in Bidoup-Nuiba evergreen forest was 0.903, and in Binh Dinh, the values were between $0.955-0.963$ [37,38], both are limestone forests in Vietnam. This could be due to the isolation of the study area and the historical human logging that destroyed the majority of forest in the area, which created a lack of seed sources from both outsides and within the area, as previously suggested by Howe et al. [39]. Moreover, limestone karst site conditions were complex, poor in nutrition, with a high percentage of exposed rocks, leading to the fact that many species did not have favorable growth context [40,41].

The result of species composition in the study area showed a large variation across three forest types. In general, the UF had the appearance of many rare and slow-growth, shade-tolerant species, each with low IVI value and none deeply dominated the landscape. This was similar to the research results in similar other non-affected natural limestone forests in Than Sa - Phuong Hoang Reserve, Vietnam [42] and Xishuangbanna National Parks, China [43].

The lack of shade-tolerant species and the appearance of 1 to 2 predominantly pioneers, light-tolerant species that overwhelm the growth of other species in SLF and especially in CCF resulted from various causes, such as these species could develop well on poor nutrient soil, high steepness; human intervention causing the destruction and disappearance of other species (i.e. invasive cultivation, logging, ecotourism, etc.). These findings presented a significant reduction in plant resources in the two logged forest types, where the valuable species found in old-growth forests were severely harvested, leaving only those with little value in SLF and none left in CCF, similar to results of other studies in secondary forests in Cat $\mathrm{Ba}$ [25] and Binh Dinh, Vietnam [38].

\subsubsection{Overstory growth characteristics}

The results represented the difference of tree community between the undisturbed core zone and the disturbed buffer zone at Cat $\mathrm{Ba}$ Biosphere Reserves. The tree density between UF and SLF was not significantly different, while it was significantly different from CCF. Other indicators were significant differences among the three forest types, with UF had much higher values than the others, indicating the consequences of logging on habitat in the study area. UF also had comparable growth characteristics with other natural limestone 
forests such as in Xishuangbanna, China $\left(\mathrm{G}=33.5 \mathrm{~m}^{2} \mathrm{ha}^{-1}\right)$, Bau Hill $\left(\mathrm{G}=28 \mathrm{~m}^{2} \mathrm{ha}^{-1}\right)$, and Gunung Mulu National Park in Sarawak, Malaysia $\left(G=37 \mathrm{~m}^{2} \mathrm{ha}^{-1}\right)[36,44,45]$. The aforementioned characteristics in SLF were also similar to other forest ecosystems in the region. In Binh Dinh, Vietnam, SLF had a tree density of $574-1,122$ stem ha $^{-1}$ and DBH of $14.3-18.1 \mathrm{~cm}$ [38], while the SLF forest in Dong Nai Biosphere Reserves in southern Vietnam had $\mathrm{G}$ of $25.7 \mathrm{~m}^{2}$ $\mathrm{ha}^{-1}$ [46]. However, CCF in the study site had much lower growth than other similarly affected forests in Vietnam. For example, in Dong Nai Biosphere Reserves, had $\mathrm{G}$ of $17.8 \mathrm{~m}^{2} \mathrm{ha}^{-1}$ [46]. CCF in Than Sa - Phuong Hoang Biosphere Reserves had DBH of $14.1 \mathrm{~cm}$ and $\mathrm{G}$ of $13.0 \mathrm{~m}^{2}$ $\mathrm{ha}^{-1}$ [47]. This suggested the intensive silvicultural measures should be applied to improve the vegetation development ability to restore the CCF in the long term.

The study of N/D distribution helped determine the horizontal distribution of the number of trees, and the previous history of impact measures (CCF or SLF). In a forest, if the N/D distribution was continuously reduced in adjacent diameter sizes, and there were many large trees $(>40 \mathrm{~cm})$, then it reflected that the forest was little or no impact, entering a phase of stability. Conversely, if the N/D distribution was interrupted, with high peaks protruding at large diameter sizes indicates that the forest has undergone SLF. The N/D distribution provides a scientific basis for classifying forest objects, thereby proposing suitable impact measures towards the restoration of forests to primeval state $[48,49]$.

In the study area, the UF and CCF follow the Meyer or Distance distribution, meaning that these forests were either not affected or had undergone widespread exploitation. The N/D distribution that many undulating and intermittent peaks, which do not follow any distribution rule in the SLF was because it has undergone selective exploitation, valuable trees with large diameter were mostly exploited, resulting in the fact that only a few trees of large diameter remained. This result was consistent with previous studies in Vietnam [35,38,46].

\subsubsection{Regeneration characteristics \\ layer \\ growth}

Factors such as forest structure (basal area, density, and canopy cover), gap, and vegetation characteristics play an important role in structuring regeneration communities [50]. It is generally recognized that the species richness of seedlings is positively associated with overstorey species abundance [51]; the species composition of regeneration communities in harvested areas appears to be determined by a complex assortment of environmental factors [50]. The ground flora, especially natural regeneration, may take advantage of any canopy openings [52].

The results in this study showed the difference in regeneration layer among the UF and SLF, CCF. The number of regenerated species in UF was much higher than in SLF and CCF because natural conditions in UF were highly stable, with the addition of seedlings from adjacent original forests that ensured the gradual development of many species. The SLF had a lower number of regenerated species than UF due to the shortage of seed supply from surrounding areas as well as the human activities in the past that caused many species to disappear from the landscape $[53,54]$. The CCF, on the other hand, had a dramatically lower number of regenerated species compared to UF and SLF, partly due to the lack of external seed supply and partly due to the poor site condition. This showed the unstable development and lack of potential to enhance biodiversity in the future in CCF. These results were consistent with previous studies $[55,56]$, in which the authors argued that the original undisturbed forest usually had a higher number of regenerated tree species than the disturbed forest.

The density and distribution of seedlings by height in the study area represent the rules of forest structure: in the younger stage, the number of seedlings is high but through growth and development, due to natural selection, the number of regenerated trees decrease, to a period of stability and development, which is called the closed canopy stage $[57,58]$. However, the seedling density in CCF decreased rapidly when reaching higher height levels was because of low canopy cover, leaving growing space for regenerated seedlings to grow, but when the seedlings reach a certain maturity level, unfavorable environment, especially a nutrient deficiency in the soil as well as the dense of shrubs well-established in this forest significantly increased the mortality of seedlings [5961]. 
Table 2. The species diversity index of the overstory layer of Unlogged forest (UF), Selectivelogged forest (SLF), Clear-cut forest (CCF)

\begin{tabular}{llll}
\hline Variables & \multicolumn{3}{c}{ Forest type } \\
\cline { 2 - 4 } & UF & SLF & CCF \\
\hline Number of species & $33^{\mathrm{a}}$ & $20^{\mathrm{b}}$ & $16^{\mathrm{c}}$ \\
Number of families & $12^{\mathrm{a}}$ & $7^{\mathrm{b}}$ & $6^{\mathrm{b}}$ \\
Gini - Simpson's index & $0.880^{\mathrm{a}}$ & $0.790^{\mathrm{b}}$ & $0.567^{\mathrm{c}}$ \\
Shannon - Weiner's index (H') & $2.353^{\mathrm{a}}$ & $1.805^{\mathrm{b}}$ & $1.163^{\mathrm{c}}$ \\
Evenness (J') & $0.910^{\mathrm{a}}$ & $0.855^{\mathrm{b}}$ & $0.679^{\mathrm{c}}$ \\
\hline \multicolumn{2}{c}{${ }^{*}$ Means followed by different letters in the same row are significantly different between forest types at $P=.05$}
\end{tabular}

Table 3. Species composition of the overstory layer of Unlogged forest (UF), Selective-logged forest (SLF), Clear-cut forest (CCF)

\begin{tabular}{|c|c|c|c|}
\hline $\begin{array}{l}\text { Forest } \\
\text { type }\end{array}$ & Species & Family & $\begin{array}{l}\text { Importance Value Index } \\
\text { (IVI) }\end{array}$ \\
\hline \multirow[t]{7}{*}{ UF } & Engelhardtia roxburghiana Wall & Juglandaceae & 11.3 \\
\hline & Dracontomelum duperreanum Pierre & Anacardiaceae & 9.6 \\
\hline & Pterospermum diversifolium Blume & Sterculiaceae & 9.5 \\
\hline & Bischofia javanica Blume & Phyllanthaceae & 6.6 \\
\hline & Dysoxylum loureirii Pierre & Meliaceae & 6.4 \\
\hline & Elaeocarpus griffithii Mast & Elaeocarpaceae & 5.5 \\
\hline & Deutzianthus tonkinensis Gagnep & Euphorbiaceae & 5.1 \\
\hline \multirow[t]{7}{*}{ SLF } & Streblus macrophyllus Blume & Moraceae & 18.2 \\
\hline & Saraca dives Pierre & Fabaceae & 13.4 \\
\hline & $\begin{array}{l}\text { Homalium paniculiflorum F.C. How \& } \\
\text { W.C. Ko }\end{array}$ & Salicaceae & 9.9 \\
\hline & $\begin{array}{l}\text { Mischocarpus pentapetalus (Roxb.) } \\
\text { Radlk }\end{array}$ & Sapindaceae & 9.8 \\
\hline & Glycosmis pentaphylla (Retz.) DC & Rutaceae & 7.7 \\
\hline & Diospyros susarticulata Lecomte & Ebenaceae & 7.2 \\
\hline & Streblus ilicifolius (S. Vidal) Corner & Moraceae & 6.6 \\
\hline \multirow[t]{7}{*}{ CCF } & Ficus auriculata Lour. & Moraceae & 25.0 \\
\hline & Streblus ilicifolius (S. Vidal) Corner & Moraceae & 17.1 \\
\hline & $\begin{array}{l}\text { Actephila longipedunculata (Merr.) } \\
\text { Croiz }\end{array}$ & Euphorbiaceae & 15.4 \\
\hline & Litsea rotundifolia Hemsl. & Lauraceae & 7.8 \\
\hline & Vitex quinata (Lour.) F.N. Williams & Lamiaceae & 6.9 \\
\hline & Streblus macrophyllus Blume & Moraceae & 6.2 \\
\hline & Glycosmis pentaphylla (Retz.) A. DC & Rutaceae & 5.5 \\
\hline
\end{tabular}

Table 4. Growth characteristics ( \pm SE) of overstory for Unlogged Forest (UF), Selective-logged forest (SLF), Clear-cut Forest (CCF)

\begin{tabular}{|c|c|c|c|}
\hline \multirow{2}{*}{ Variables } & \multicolumn{3}{|c|}{ Forest type } \\
\hline & UF & SLF & CCF \\
\hline Density (stems ha ${ }^{-1}$ ) & $800 \pm 175^{a}$ & $817 \pm 189^{a}$ & $1,117 \pm 161^{6}$ \\
\hline $\mathrm{DBH}(\mathrm{cm})$ & $20.6 \pm 13.7^{\mathrm{a}}$ & $16.9 \pm 9.7^{b}$ & $10.5 \pm 3.8^{\mathrm{C}}$ \\
\hline $\mathrm{G}\left(\mathrm{m}^{2} h \mathrm{a}^{-1}\right)$ & $38.2 \pm 10.3^{a}$ & $24.0 \pm 5.7^{b}$ & $11.4 \pm 5.6^{c}$ \\
\hline Canopy cover (\%) & $79.3 \pm 9.1^{\mathrm{a}}$ & $62.4 \pm 4.5^{b}$ & $52.7 \pm 7.4^{\mathrm{c}}$ \\
\hline
\end{tabular}

${ }^{*} \mathrm{DBH}$ is diameter at breast height, $\mathrm{G}$ is stem basal area. Means followed by different letters in the same row are significantly different between forest types at $P=.05$ 

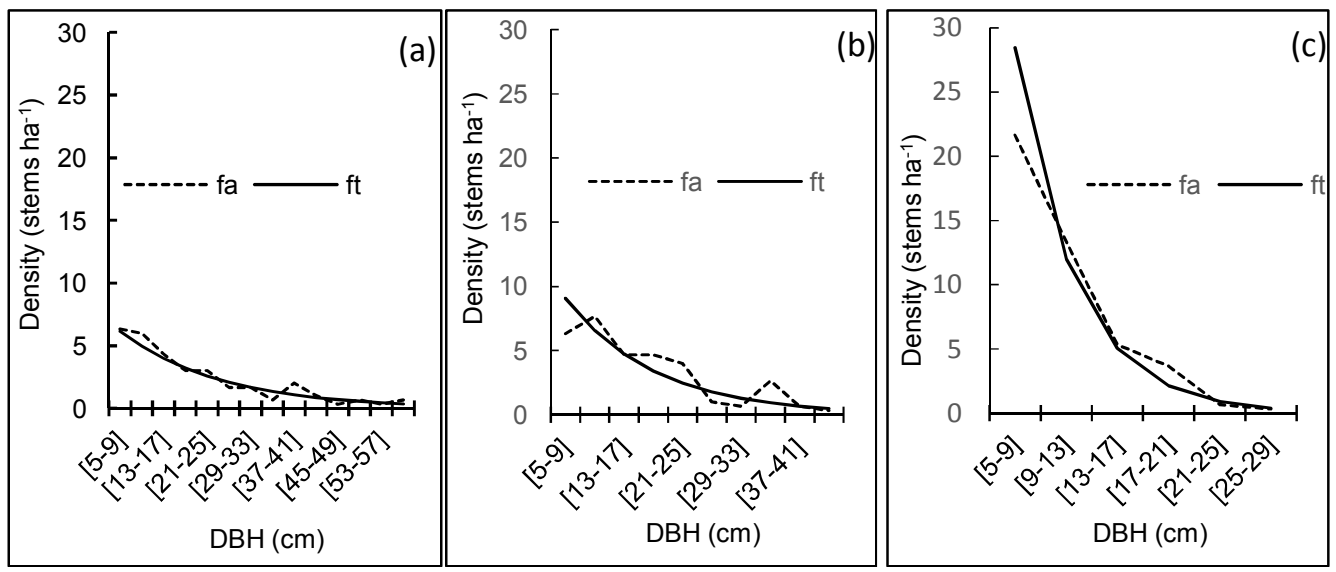

Fig. 3. N/D distribution, (a) Unlogged forest, (b) Selective-logged forest, (c) Clear-cut forest $f a$ is actual frequency, $f t$ is the theoretical frequency

Table 5. Natural regeneration characteristics of Unlogged forest (UF), Selective-logged forest (SLF), Clear-cut forest (CCF)

\begin{tabular}{|c|c|c|c|}
\hline \multirow[t]{2}{*}{ Variables } & \multicolumn{3}{|c|}{ Forest type } \\
\hline & UF & SLF & CCF \\
\hline Number of species & $35^{\mathrm{a}}$ & $13^{\mathrm{b}}$ & $5^{\mathrm{c}}$ \\
\hline Density (seedlings ha ${ }^{-1}$ ) & $8,373 \pm 5,041^{a}$ & $21,733 \pm 5,148^{b}$ & $43,573 \pm 19,766^{c}$ \\
\hline
\end{tabular}

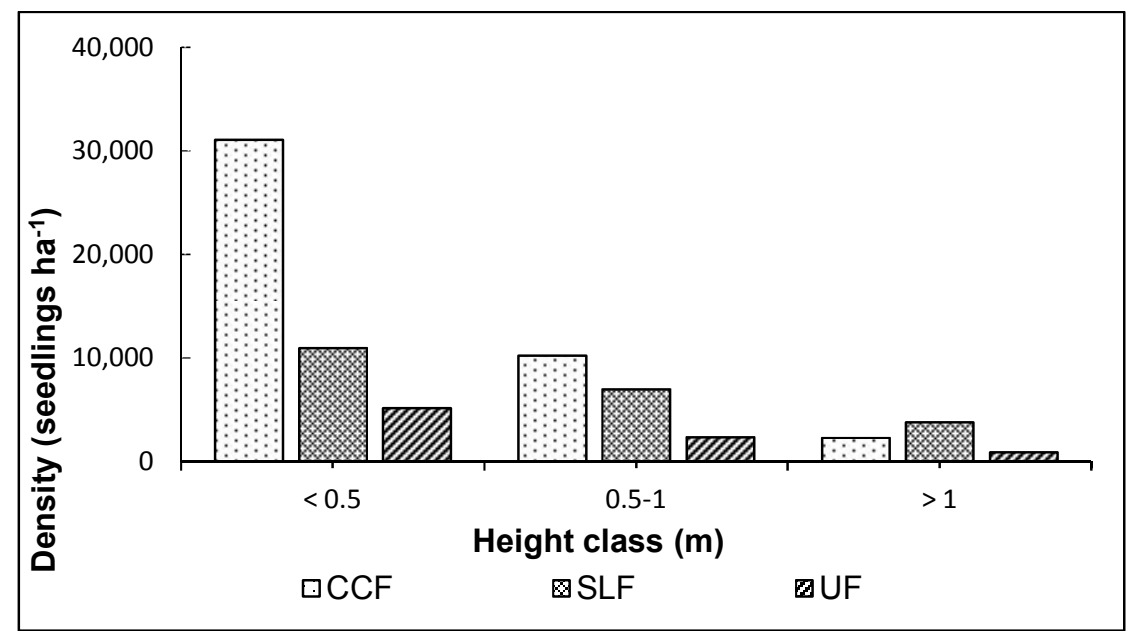

Fig. 4. Seedling distribution by height. Unlogged forest (UF), Selective-logged forest (SLF), Clear-cut forest (CCF)

\section{CONCLUSION}

The results obtained from this study showed that the forest structure in SLF and especially CCF was degraded from that in UF because of historical human activities in the study area. The CCF had low and unstable growth of overstory plants with poor regeneration and low biodiversity, dominated by mostly pioneer species. The SLF had better development than the CCF but the biodiversity level was recorded still low. UF was characterized by good growth and development parameters, which were superior to SLF and CCF, but low species richness here represented that the site condition in the study area, namely limestone bedrocks was not as favorable for plants compared to other forests in Vietnam. 


\section{ACKNOWLEDGEMENTS}

This research was funded by the Ministry of Science and Technology under grant No. 25/17/DTDL.CN-XHNVTN. We thank colleagues from Silviculture Research Institute and Cat $\mathrm{Ba}$ National Park for invaluable assistance in data collection and analysis. We would like to thank anonymous for their valuable comments on earlier drafts of the manuscript.

\section{COMPETING INTERESTS}

Authors have declared that no competing interests exist.

\section{REFERENCES}

1. Tang JW, Yin JX, Qi JF, Jepsen MR, Lu $\mathrm{XT}$. Ecosystem carbon storage of tropical forests over limestone in Xishuangbanna, SW China. Journal of Tropical Forest Science. 2012;24:399-407.

2. Crottini A, Glaw F, Casiraghi M, Jenkins RK, Mercurio V, Randrianantoandro C et al. A new Gephyromantis (Phylacomantis) frog species from the pinnacle karst of Bemaraha, western Madagascar. Zookeys. 2011;81:51-71.

3. Bogutskaya NG, Zupancic P, Bogut I, Naseka AM. Two new freshwater fish species of the genus Telestes (Actinopterygii, Cyprinidae) from karst poljes in Eastern Herzegovina and Dubrovnik littoral (Bosnia and Herzegovina and Croatia). Zookeys. 2012;180: 53-80.

4. Chen WH, Shui YM, Yang JB, Wang $\mathrm{H}$, Nishii K, Wen $F$ et al. Taxonomic status, phylogenetic affinities and genetic diversity of a presumed extinct genus, Paraisometrum W.T. Wang (gesneriaceae) from the karst regions of Southwest China. PLoS One. 2014;9(9):107967.

5. Peng $\mathrm{Cl}$, Lin $\mathrm{CW}$, Yang $\mathrm{HA}$, Kono $\mathrm{Y}$, Nguyen $H Q$. Six new species of Begonia (Begoniaceae) from limestone areas in Northern Vietnam. Bot Stud. 2015;56:9.

6. Perez-Garcia EA, Sevilha AC, Meave JA, Scariot A. Floristic differentiation in limestone outcrops of southern Mexico and central Brazil: a beta diversity approach. Boletin de la Sociedad Batanica de Mexico. 2009;84:45-58.

7. $\mathrm{Li} \mathrm{C}$, Xiong $\mathrm{K}, \mathrm{Wu} \mathrm{G}$. Process of biodiversity research of Karst areas in China. Acta Ecol Sin. 2013;33:192-200.
8. Liu CQ. Biogeochemical Processes and the Surface Material Cycle: The Cycles of Biogenic Elements of Soil - Vegetation System in the Southwestern Karst China. Science Press, Beijing, China; 2009.

9. Liu CC, Liu YG, Fan DY, Guo K. Plant drought tolerance assessment for revegetation in heterogeneous karst landscapes of southwestern China. Flora Morphol Distrib Funct Ecol Plants. 2012;207:30-38.

10. Saw LG, Chua LSL, Rahim NA, editor. Malaysia National Strategy for Plant Conservation. Ministry of Natural Resources and Environment and Forest Research Institute Malaysia, Selangor, Malaysia; 2009.

11. Brinkmann $R$, Parise $M$. Karst environments: Problems, management, human impacts, and sustainability. An introduction to the special issue. J Cave Karst Stud. 2012;74(2):135-136.

12. Asner GP, Rudel TK, Aide TM, Defries R, Emerson R. A contemporary assessment of change in humid tropical forests. Conserv. Biol. 2009;23:1386-1395.

13. Morales-Hildago D, Oswalt SN, Somanathan E. Status and trends in global primary forest, protected areas, and areas designated for conservation of biodiversity from the Global Forest Resources Assessment 2015. Forest Ecology and Management. 2015;352:68-77.

14. Edwards DP, Tobias JA, Sheil D, Meijaard $E$, Laurance WF. Maintaining ecosystem function and services in logged tropical forests. Trends in ecology \& evolution. 2014;29(9):511-520.

15. Kelly DL, Tanner EVJ, Kapos V, Dickinson TA, Goodfriend GA, Fairbairn $P$. Jamaincan limestone forests: floristics, structure and environment of three examples along a rainfall gradient. Journal of Tropical Ecology. 1988;4:121-156.

16. Felfili JM, Narcimento ART, Fagg CW, Meirelles EM. Floristic composition and community structure of a seasonally deciduous forest on limestone outcrops in central Brazil. Revista Brasileira de Botanica. 2007;30:611-621.

17. Baur GN. The Ecological Basis of Rain Forest Management. Department of Conservation, Sydney, New South Wales, Australia; 1965.

18. Trung TV. Vietnam forest vegetation from the perspective of ecosystems. Science and Technology Publisher, Hanoi;1999. 
19. Brewer SW, Reimanek M, Webb MAH, Fine PVA. Relationship of phytogeography and diversity of tropical tree species with limestone topography in southern Belize. Journal of Biogeography. 2003;30:16691688.

20. 20. Hai Phong City Statistical Office. Hai Phong Statistical Yearbook of 2018. Statistical Publishing House, Hanoi; 2018.

21. Viet $\mathrm{H}$, Lin CK. Cat Ba National Park, Viet Nam. ITCZM Monograph No.2: AIT, Thailand; 2001.

22. Zingerli C. Colliding understandings of biodiversity conservation in Vietnam: Global claims, national interests, and local struggles. Society \& Natural Resources. 2005;18(8):733-747.

23. Brooks A. Enhancing the Effectiveness of Projects on Cat Ba Island - an Evaluation of Ten Years of International Support. International Union for Conservation of Nature (IUCN) Vietnam Country Office, Hanoi; 2006.

24. Le TC. Vietnam's nature. Science and Technical Publishing House. Hanoi, Vietnam; 1990.

25. Thap HV. Proposing some technical solutions for rehabilitation of poor limestone forest in Cat Ba National Park, Vietnam. PhD thesis. Vietnam National University of Forestry, Hanoi; 2010.

26. Marmillod D. Methodik und Ergebnisse von Untersuchungen über Zusammensetzung und Aufbau eines Terrassenwaldes im perauanischen Amazonien. Georg-AugustUniversität zu Göttingen. German; 1982.

27. Jost L. Entropy and diversity. Oikos. 2006;113:363-375.

DOI:10.1111/j.2006.0030-1299.14714.x.

28. Shannon CE. A mathematical theory of communication. The Bell System Technical Journal. 1948;27:379-423 and 623-656.

29. Pielou EC. The measurement of diversity in different types of biological collections. Journal of Theoretical Biology. 1966;13:131-144.

30. Harding KA, Ford DC. 1993. Impacts of primary deforestation upon limestone slopes in northern Vancouver Island, British Columbia. Environmental Geology. 1993;21:137-14.

31. Richards PW. The tropical rain forests. Cambridge University Press, London; 1952.

32. Molino JF, Sabatier D. Tree diversity in tropical rain forests: a validation of the intermediate disturbance hypothesis. Science. 2001;294:1702-1704.

33. Ngo TL, Holscher D. The fate of five rare tree species after logging in a tropical limestone forest (Xuan Son National Park, northern Vietnam). Tropical Conservation Science. 2014;7(2):326-341.

34. Cao M, Zhang JH. Tree species diversity of tropical forest vegetation in Xishuangbanna, SW China. Biodiversity and Conservation. 1997;6:995-1006.

35. Hien NTT, Con TV, Ha TTT. Structural dynamics of evergreen broadleaves forest in Babe National Park. Journal of Forestry Science and Technology. 2014;3:34173423.

36. Adam JH, Mamat Z. Floristics composition and structural comparison of limestone forest at three different elevations in Bau, Kuching, Sarawaj, Malaysia. Journal of Biological Science. 2005;5:478-485.

37. Binh NT. Some structural characteristics and biodiversity of mixed tropical evergreen forest in Bidoup-Nuiba National Park. Journal of Forestry Science and Technology. 2014;2:3255-3263.

38. Van PQ, Hien CTT. 2018. Structural characteristics and species diversity of canopy layer vegetation in natural forest of An Lao, Binh Dinh. Journal of Forestry Science and Technology. 2018;01.

39. Howe HF, Small WJ. Ecology of seed dispersal. Annual review of ecology and systematics. 1982;13(1):201- 228.

40. Crowther J. Groundwater chemistry and cation budgets of tropical karst outcrops, Peninsular Malaysia, I. Calcium and magnesium. J Hydrol. 1989;107:169-192.

41. Nie YP, Chen HS, Wang KL, Yang J. Water source utilization by woody plants growing on dolomite outcrops and nearby soils during dry seasons in karst region of Southwest China. J Hydrol. 2012;420421,264-274.

42. Thoa NT. Analysis of some biodiversity indicators of limestone forest in Than Sa Phuong Hoang Natural Reserve, Thai Nguyen, Vietnam. Journal of Forestry Science and Technology. 2013;4:29612967.

43. Liu JJ, Slik JWF. Forest fragment spatial distribution matters for tropical tree conservation. Biological Conservation. 2014;171:99-106.

44. Proctor J, Anderson JM, Chai P, Vallack $\mathrm{HW}$. Ecological studies in four contrasting lowland rain forests in Gunung Mulu 
National Park, Sarawak. Journal of Ecology. 1983;71:237-260.

45. Tang JW, Lu XT, Yin JX, Qi JF. Diversity, composition and physical structure of tropical forest over limestone in Xishuangbanna, Southeast China. Journal of Tropical Forest Science. 2011;23:425433.

46. Trung PD, Dong TL, Tuyen PQ, Khuong NV, Phuong NTT, Quy TH. Structural characteristics and biodiversity of postexploitation restoration forest in Dong Nai Natural Reserve. Journal of Forestry Science and Technology. 2016;4:46374645.

47. Chung DH, Hung NT. Structural, living mass and carbon sequestration characteristics of natural forests in Sang Moc commune, Than Sa - Phuong Hoang Natural Reserve. Proceedings of the Fifth National Scientific Convention on Ecology and Biological Resources. Institute of Ecology and Biological Resources, Vietnam Academy of Science and Technology, Vietnam; 2013.

48. Bryan F, Marlen C, Nelson Z. Diameter increment patterns among 106 tree species in a logged and silviculturally treated Costa Rican rain forest. Forest Ecology and Management. 1999;121(3): 159 - 176.

Available: https://doi.org/10.1016/S03781127(98)00551-9.

49. Hall JS, Harris DJ, Medjibe, V, Ashton PM. $S$. The effects of selective logging on forest structure and tree species composition in a Central African forest: implications for management of conservation areas. Forest Ecology and Management. 2003;183(13):249-264.

50. Park A, Joaqiun JM, Fredericksen TS. Natural regeneration and environmental relationships of tree species in logging gaps in a Bolivian tropical forest. Forest Ecology and Management. 2005;217:147157.

51. Denslow JS, Guzman GS. Variation in stand structure, light and seedling abundance across a tropical moist forest chronosequence, Panama. Journal of Vegetation Science. 2000;11:201-212.

52. Madsen $P$, Larsen JB. Natural regeneration of beech (Fagus sylvatica L.) with respect to canopy density, soil moisture and soil carbon content. Forest Ecology and Management. 1997;97:95105.

53. Chinea JD. Tropical forest succession on abandoned farms in the Humacao municipality of eastern Puerto Rico. Forest Ecology and Management. 2002;167:195207.

54. Dent DH, Wright SJ. The future of tropical species in secondary forests: a quantitative review. Biological conservation. 2009;142(12):2833-2843.

55. Perry P, Morton JM. Regeneration rates of the woody vegetation of Guam's Northwest Field following major disturbance: land use patterns, feral ungulates, and cascading effects of the brown treesnake. Micronesica. 1999;31(2):125-142.

56. Haggar J, Wightman K, Fisher R. The potential of plantations to foster woody regeneration within a deforested landscape in lowland Costa Rica. Forest Ecology and Management. 1997;99(1-2);55-64.

57. Kramer PJ, Kozlowski TT. Physiology of Woody Plants. Academic, New York, 811 pp; 1979.

58. Oliver CD, Larson BC. Forest stand dynamics: updated edition. John Wiley and Sons, New York; 1996.

59. Parrotta JA. Influence of overstory composition on understory colonisation by native species in plantations on a degraded tropical site. Journal of Vegetation Science. 1995;6:627-636.

60. Chapman CA, Chapman LJ. Forest regeneration in logged and unlogged forests of Kibale National Park, Uganda. Biotropica. 1997;29(4):396-412.

61. Van Thinh N, Mitlöhner R, Van Bich N. Comparison of floristic composition in four sites of a tropical lowland forest on the North-Central Coast of Vietnam. Journal of Nature and Science. 2015;1(8):144.

(c) 2020 Long et al.; This is an Open Access article distributed under the terms of the Creative Commons Attribution License (http://creativecommons.org/licenses/by/4.0), which permits unrestricted use, distribution, and reproduction in any medium, provided the original work is properly cited.

Peer-review history:

The peer review history for this paper can be accessed here: http://www.sdiarticle4.com/review-history/64612 